\title{
PENGEMBANGAN SUPLEMEN PENUNTUN PRAKTIKUM TAKSONOMI TUMBUHAN TINGGI BERDASARKAN STUDI ETNOBOTANI TUMBUHAN MANGROVE DI KOTA BENGKULU
}

\author{
Wahyu Masyhuri Permana ${ }^{1 *}$, Kasrina ${ }^{1}$, Irwandi Ansori ${ }^{1}$ \\ ${ }^{1}$ Program Studi Pendidikan Biologi, Fakultas Keguruan dan Ilmu Pendidikan, Universitas Bengkulu \\ Email: mamasmasyhuri86@gmail.com
}

\begin{abstract}
Abstrak
Penelitian ini bertujuan untuk mengetahui kelayakan suplemen penuntun praktikum Taksonomi Tumbuhan tinggi yang dikembangkan berdasarkan studi etnobotani pemanfaatan tumbuhan mangrove di Kota Bengkulu oleh masyarakat sekitar kawasan hutan mangrove berdasarkan uji validasi dan uji keterbacaan pada mahasiswa pendidikan biologi UNIB. Wawancara kepada masyarakat dilakukan di 3 lokasi yaitu daerah sekitar hutan mangrove Kampung Bahari, hutan mangrove di kelurahan Sumber Jaya dan Padang Serai serta hutan mangrove di Taman Wisata Alam Pantai Panjang dan Pulau Baai kelurahan Muara Dua kecamatan Kampung Melayu Kota Bengkulu. Pengembangan suplemen penuntun praktikum berdasarkan studi etnobotani oleh peneliti. Validasi dilakukan oleh ahli materi dan ahli bahan ajar serta uji keterbacaan terhadap mahasiswa pendidikan biologi UNIB. Hasil uji validasi penuntun praktikum yang dilakukan oleh 1 orang ahli materi dan 1 orang ahli bahan ajar mendapatkan hasil masing-masing ialah $78 \%$ dan $75 \%$ dengan kriteria valid, dan hasil uji keterbacaan pada mahasiswa yaitu $86 \%$ dengan kriteria sangat layak sehingga penuntun praktikum Taksonomi Tumbuhan tinggi yang telah dikembangkan, layak digunakan sebagai bahan ajar matakuliah Taksonomi Tumbuhan.
\end{abstract}

Kata Kunci : Etnobotani, Pemanfaatan Mangrove, Penuntun Praktikum, Taksonomi Tumbuhan Tinggi

\begin{abstract}
This research aims to determine the feasibility of supplemental guidance on high plant taxonomy practicum developed based on ethnobotany studies on the utilization of mangrove plants in the city of Bengkulu by the community around the mangrove forest area based on validation tests and readability tests on UNIB biology education students. Community interviews were conducted in 3 locations, namely the area around Kampung Bahari mangrove forest, mangrove forests in Sumber Jaya and Padang Serai villages and mangrove forests in Pantai Panjang Nature Park and Baai Island in Muara Dua Village, Kampung Melayu District, Bengkulu City. Developed practicum supplement based on ethnobotany studies conducted for researcher. Validation was carried out by material experts and teaching materials experts as well as readability tests of UNIB biology education students. The results of the practicum guideline test conducted by 1 material expert and 1 teaching material expert get the results of each of them is $78 \%$ and $75 \%$ with valid criteria, and the readability test results for students are $86 \%$ with very feasible criteria so that the taxonomy practicum guide tall plants that have been developed, deserve to be used as teaching materials for plant taxonomy.
\end{abstract}

Keywords: Ethnobotany, Mangrove Utilization, Practical Guide, High Plant Taxonomy

\section{PENDAHULUAN}

Kompetensi lulusan S1 pendidikan biologi menerapkan penguasaan konsep biologi dan ilmu pendidikan dalam merancang pembelajaran biologi dengan

memanfaatkan perkembangan IPTEKS serta sesuai dengan standar nasional pendidikan, permasalahan dikelas dan sekolah, perkembangan peserta didik dan 
karakteristik lingkungannya sehingga menghasilkan desain pembelajaran yang mendorong partisipasi aktif dan mengembangkan potensi setiap peserta didik, peserta didik mampu mencapai tujuan pendidikan dan mengaktualisasikan berbagai potensi yang dimilikinya dan menghasilkan informasi yang bermakna dalam pengambilan keputusan, serta mampu mengambil keputusan perbaikan mutu pembelajaran biologi dikelas maupun disekolah berdasarkan hasil refleksi pembelajaran yang dilakukan secara mandiri maupun kolaboratif (Tim Penyusun Prodi Pendidikan Biologi, 2018).

Berdasarkan kompetensi lulusan tersebut, dapat dicapai melalui mata kuliah wajib dan pilihan. Pada program studi pendidikan biologi salah satu mata kuliah yang tersedia adalah Taksonomi Tumbuhan II. Taksonomi Tumbuhan adalah ilmu yang mempelajari tentang prinsip dan konsep taksonomi, hirarki taksonomi, deskripsi, identifikasi, sumber bukti taksnonomi, tatanama, herbarium, kebun raya dan arboreta, kepustakaan taksnomi, klasifikasi pinophyta, magnoliophyta, serta pusat keragaman tumbuhan dan etnobotani. Salah satu Kompetensi Dasar(KD) yang ada pada mata kuliah Taksonomi Tumbuhan II adalah "Menganalisis pusat keragaman tumbuhan dan etnobotani", dengan materi yang membahas tentang "Peranan etnobotani dalam mendokumentasikan pengetahuan orang kampung tentang sumber daya alam"(Tim Penyusun Prodi Pendidikan Biologi, 2017).

Dalam meningkatkan pemahaman mahasiswa terhadap pembelajaran Taksonomi Tumbuhan II, salah satu upaya yang dilakukan adalah praktikum yang berguna menunjang pengembangan keterampilan proses sains peserta didik.
Penerapan Keterampilan Proses Sains sekaligus pengembangan sikap ilmiah yang mendukung proses pengetahuan dalam diri peserta didik dalam hal ini mahasiswa sangat dimungkinkan dalam kegiatan praktikum, sehingga dalam pembelajaran Ilmu Pengetahuan Alam praktikum memiliki kedudukan yang amat penting. Sedangkan praktikum itu sendiri merupakan kegiatan pembelajaran yang bertujuan agar siswa mendapat kesempatan untuk menguji dan mengaplikasikan teori dengan menggunakan fasilitas laboratorium maupun di luar laboratorium (Rustaman, 2005). Berdasarkan hasil observasi dan wawancara belum adanya praktikum tentang materi pada KD tersebut, sehingga praktikum mengenai studi etnobotani mangrove diharapkan dapat dilakukan oleh peserta didik.

Mangrove sebagai fungsi ekologi diantaranya sebagai penyerap polutan; tempat terjadinya daur ulang unsur hara; tempat berpijahnya aneka biota laut; tempat berkembang biaknya aneka jenis burung, mamalia, reptile dan serangga; sebagai sumber plasma nutfah; sebagai biofilter alami; dan memiliki kemampuan menyimpan karbon yang tinggi. Sebagai fungsi ekonomi, ekosistem mangrove menyediakan hasil lingkungan hutan berupa kayu dan non kayu (Noor, 2006).

Dalam kehidupan sehari-hari masyarakat sekitar kawasan hutan mangrove banyak memanfaatkan potensi produksi yang ada di dalamnya, baik sumberdaya kayunya maupun sumberdaya biota air (udang, kepiting, ikan) yang biasanya hidup dan berkembang biak di hutan mangrove. Mangrove banyak dijumpai di wilayah pesisir yang terlindung dari gempuran ombak dan daerah yang landai di daerah tropis dan sub tropis. 
Menurut Noor (2006) Masyarakat di kawasan pesisir atau sekitar hutan mangrove banyak menggunakan tumbuhan mangrove sebagai bahan sandang, pangan, dan papan. Produk hutan mangrove yang sering dimanfaatkan manusia adalah kayu yang digunakan sebagai bahan bakar, bahan membuat perahu, tanin untuk pengawet jaring, lem, bahan pewarna kain dan lainlain.

Menurut Martin (1998), Etnobotani adalah segala bentuk pengetahuan (mengenai tumbuhan) yang menggambarkan hubungan antara masyarakat lokal (etnis) dengan sumberdaya alam. Ilmu etnobotani sangat besar manfaatnya, khususnya bagi masyarakat yang tinggal di kawasan mangrove. Etnobotani berkembang dari hanya menaruh perhatian terhadap pengumpulan informasi, jenis-jenis dan nama lokal dari tumbuhan hingga manfaat tertentu yang ada pada masyarakat. Selain itu dalam etnobotani juga mempelajari hubungan timbal balik secara menyeluruh antara masyarakat lokal dengan alam lingkungannya yang meliputi pengetahuan tentang sumberdaya alam tumbuhan. Etnobotani berpotensi mengungkapkan sistem pengetahuan tradisional dari suatu kelompok masyarakat atau etnik mengenai keanekaragaman sumberdaya hayati, konservasi dan budaya (Purwanto 2000). Berdasarkan uraian di atas, maka penting dilakukan penelitian tentang "Pengembangan suplemen penuntun praktikum Taksonomi Tumbuhan II Berdasarkan Studi Etnobotani Tumbuhan Mangrove di Kota Bengkulu".

\section{METODE}

Pada penelitian ini menggunakan metode Penelitian dan Pengembangan
(Research and Development) dengan langkah-langkah mengadopsi dari Sugiyono (2012). Penelitian ini dilakukan pada bulan Januari s/d Mei 2019 untuk penyusunan suplemen penuntun praktikum dan diuji validasi oleh ahli serta uji keterbacaan terhadap mahasiswa pendidikan Biologi FKIP Universitas Bengkulu.

Subjek penelitian adalah Mahasiswa Pendidikan Biologi yang menempuh mata kuliah Taksonomi Tumbuhan II. Teknik pengumpulan data pada penelitian ini menggunakan tiga kategori angket yaitu angket uji kelayakan untuk validator dan angket keterbacaan suplemen penuntun praktikum untuk mahasiswa.

Pengembangan suplemen penuntun praktikum dimulai dari penyusunan suplemen penuntun praktikum dengan struktur yang telah ditentukan. Struktur suplemen penuntun praktikum mengikuti struktur yang di rancang oleh JPMIPA FKIP Universitas Bengkulu. Hal tersebut di perbolehkan sesuai dengan Permendikti Nomor 75 tahun 2013 yang menyatakan bahwa selama tujuan pembelajaran untuk memajukan ilmu pengetahuan maka civitas akademisi diperbolehkan mengembangkan bahan ajar pada suatu instansi akademisi.

Pengembangan yang dilakukan pada suplemen penuntun praktikum Taksonomi Tumbuhan II ini meliputi penambahan topik baru pada materi etnobotani. Pengembangan suplemen penuntun praktikum di buat juga menyesuaikan dengan KD yang dibutuhkan dan selanjutya disatukan dengan penuntun Taksonomi Tumbuhan II sebelumnya.

Data uji validasi suplemen penuntun praktikum oleh validator dan uji keterbacaan yang terkumpul dianalisis secara deskriptif kuantitatif. Dalam proses validasi ini menghadirkan 2 orang ahli 
diantaranya yaitu 1 orang dosen biologi yaitu ahli materi yang merupakan dosen matakuliah Taksonomi Tumbuhan II dan 1 orang ahli bahan ajar.

Angka hasil uji validasi dan uji keterbacaan yang diperoleh diubah ke dalam persentase kelayakan dengan rumus berikut :

Persentase $=\frac{\text { Jumlah skor lembar validasi }}{\text { Skor maksimal }} \times 100 \%$
Hasil analisis data dari uji validasi dan uji keterbacaan suplemen penuntun praktikum yang berupa persentase tersebut kemudian di interpretasikan dengan menggunakan panduan tabel kriteria penilaian hasil validasi yang dapat dilihat pada Tabel 1 :

(Riduwan, 2015).

Tabel 1. Kriteria Penilaian Hasil Validasi dan Uji Keterbacaan Suplemen Penuntun Praktikum

\begin{tabular}{ccc}
\hline Skala Nilai & Keterangan & Keputusan Uji \\
\hline $86-100$ & Sangat Valid & $\begin{array}{c}\text { Sangat layak dan tidak reevisi jika } \\
\text { mencapai } 100 \%\end{array}$ \\
$71-85$ & Valid & Layak namun tetap dilakukan revisi \\
kecil \\
$56-70$ & Cukup Valid & Cukup layak dan perlu revisi besar \\
$41-55$ & Kurang Valid & Kurang layak dan perlu revisi besar \\
$25-40$ & Sangat kurang valid & Tidak layak dan perlu revisi besar \\
\hline
\end{tabular}

(Akbar, 2013).

\section{HASIL DAN PEMBAHASAN}

Suplemen penuntun praktikum yang telah didesain divalidasi oleh dua dosen ahli yaitu ahli bahan ajar dan ahli materi serta uji keterbacaan terhadap mahasiswa pendidikan biologi yang sudah mengambil mata kuliah Taksonomi Tumbuhan II. Adapun hasil dari validasi oleh 2 validator dapat dilihat pada Tabel 2 :

Tabel 2. Hasil Analisis Uji Validasi

\begin{tabular}{clcc}
\hline No & Validator & Skor Akhir & Persentase \\
\hline 1 & Ahli Bahan Ajar & 28 & $78 \%$ \\
2 & Ahli Materi & 27 & $75 \%$ \\
\hline \multicolumn{3}{c}{ Rerata } & $76,39 \%$ \\
\hline
\end{tabular}

Berdasarkan hasil validasi oleh ahli materi, dan ahli bahan ajar mendapatkan hasil $76 \%$ dengan katagori "valid". Kriteria yang diperoleh dari masing-masing ahli yaitu layak dengan revisi sebelum dilakukan uji keterbacaan. Dengan demikian, suplemen penuntun praktikum hasil pengembangan dari penelitian pemanfaatan tumbuhan mangrove layak untuk uji keterbacaan setelah revisi berdasarkan saran dari validator.

Setelah suplemen penuntun praktikum dilakukan uji validasi oleh ahli materi dan ahli bahan ajar maka dilakukan revisi dengan masukan yang diberikan oleh para validator. Masukan dan saran dari ahli bahan ajar yaitu :

1) Penulisan diperhatikan kesalahan penulisan huruf, angka dan spasi.

2) Penulisan dan tata bahasa diperhatikan.

3) Serta masukan dari ahli materi yaitu "judul kegiatan praktikum kurang tepat yang seharusnya pemanfatn mangrove, 
sitasi dalam materi tidak tercantum, antar paragraf tidak menunjukan hubungan ulasan seharusnya media dikembangkan mengenai kajian tentang jenis mangrove, daftar pustaka konsep dilengkapi dalam setiap judul kegiatan".

Setelah dilakukan revisi terhadap penuntun praktikum selanjutnya dilakukan uji keterbacaan. Adapun hasil dari uji keterbacaan oleh mahasiswa biologi dari hasil pengembangan Suplemen penuntun praktikum disajikan dalam Tabel 3 yaitu sebagai berikut :

Tabel 3. Rekapitulasi Respon Mahasiswa/Uji Keterbacaan Terhadap Suplemen Penuntun Praktikum

\begin{tabular}{clccc}
\hline No & \multicolumn{1}{c}{$\begin{array}{c}\text { Aspek Yang Diuji } \\
\text { Keterbacaan }\end{array}$} & $\begin{array}{c}\text { Jumlah Skor Yang } \\
\text { Diperoleh }\end{array}$ & $\begin{array}{c}\text { Jumlah Skor } \\
\text { Keseluruhan }\end{array}$ & Persentase \\
\hline \multirow{2}{*}{$\begin{array}{l}\text { Komponen Kelayakan } \\
\text { Materi Atau Isi }\end{array}$} & 716 & 840 & $85 \%$ \\
2 & Komponen Bahasa & 241 & 280 & $86 \%$ \\
3 & Komponen Grafis & 486 & 560 & $87 \%$ \\
& Jumlah & 1443 & 1680 & $86 \%$ \\
\hline
\end{tabular}

Berdasarkan data pada Tabel 3 diketahui bahwa kriteria suplemen penuntun praktikumyang direspon oleh mahasiswa mendapatkan hasil yang "Sangat layak" dengan persentase $86 \%$. Hasil analisis menunjukkan bahwa seluruh kriteria mendapatkan respon positif $100 \%$ dengan skor respon $86 \%$ dari 35 mahasiswa. Pada Salah satu komentar dan saran mahasiswa mengenai suplemen penuntun praktikum yaitu, pembuatan dan pelaksanaan praktikum ini sangat baik dilaksanakan, selain memberi ilmu pengetahuan yang lebih juga dapat memberi nilai ekonomis.

Adapun desain dari suplemen penuntun praktikum yang telah dikembangkan terdiri dari:

\section{1) Cover}

Cover pada suplemen penuntun berisikan judul media yang dikembangkan serta foto kegiatan.
2) Kata pengantar

Kata Pengantar berisi ucapanucapan atas selesainya penulisan karya tulis baik tentang ucapan rasa syukur, ucapan rasa terima kasih, tujuan dan manfaat penulisan serta kritik dan saran yang membangun. Kata pengantar terbagi dalam 3 bagian yaitu pembukaan, isi dan penutup.

3) Daftar isi

Daftar isi berisi halaman judul, kata pengantar, daftar isi, pendahuluan, topik, daftar pustaka serta lampiran.

4) Pendahuluan

Pendahuluan pada suplemen penuntun praktikum berisi uraian mengenai karakteristik mangrove serta jenis-jenis magrove yang ditemukan dalam penelitian.

5) Topik

Topik pada penuntun beriskan judul materi yang akan dilakukan praktikum dengan format size font 14, kapital dan 
bold. Selanjutnya tujuan berisikan pencapaian yang diharapkan dari kegiatan praktikum. Kemudian indikator pencapaian berisikan point-point penting yang ingin di capai pada praktikum yang akan dilaksanakan. Materi pada suplemen penuntun praktikum berikan penjelasan mengenai etnobotani dan pemanfaatan mengenai mangrove.

Alat dan bahan yaitu bagian yang menerangkan apa saja alat yang digunakan dan bahan yang dibutuhkan dalam proses praktikum. Kemudian langkah kerja yang menuntun bagaiman proses yang harus dilakukan dalam praktikum hingga menghsilkan produk setelahnya nanti. Kemudian daftar pertanyaan adalah pertanyaan yang di ajukan kepada praktikan mengenai praktikum sehingga mahasiswa bisa menarik kesimpulan dari kegiatan praktikum tersebut

\section{6) Daftar pustaka}

Berisi referensi dalam melengkapi isi dari suplemen penuntun praktikum, referensi yang didapatkan berasal dari buku-buku serta jurnal yang ada di internet.

\section{7) Lampiran}

Lampiran pada suplemen penuntun praktikum berisikan rubrik penilaian.

Setelah suplemen penutun didesain selanjutnya di uji validasi oleh ahli materi dan ahli bahan ajar. Tujuan dari tahap ini adalah melihat validitas dan mendapatkan saran terhadap suplemen penuntun praktikum sebelum dilakukan uji keterbacaan pada mahasiswa.

Berdasarkan hasil analisis data dari ahli materi pada suplemen penuntun praktikum yang telah dibuat, didapatkan kriteria/hasil uji validasi oleh ahli bahan ajar telah "valid" dengan persentase $78 \%$. Hasil analisis uji validasi dari ahli bahan ajar yang telah dilakukan memerlukan adanya revisi dengan masukan yaitu "penulisan diperhatikan kesalahan penulisan huruf, angka dan spasi. Penulisan dan tata bahasa diperhatikan".

Revisi yang dilakukan karena spasi antar kata pada suplemen penuntun praktikum yang tidak ada karena proses pencetakan penuntun menggunakan aplikasi software yang berbeda. Berdasarkan saran dari validator, maka penulis melakukan revisi dengan mencetak ulang dengan software yang sama saat pengeditan.

Hasil analisis dari ahli materi telah valid dengan persentase $75 \%$. Hasil analisis uji validasi dari ahli materi yang telah dilakukan juga memerlukan beberapa revisi. Diantaranya revisi yang diperlukan pada suplemen penuntun praktikum adalah perubahan topik dari pemanfaatan dodol mangrove menjadi pemanfaatan mangrove pidada (Sonneratiaalba), kemudian materi yang ditambah serta sitasi pada setiap paragraf yang belum di letakan sebelumnya dan melengkapi daftar pustaka.

Berdasarkan kedua hasil analisis tersebut, maka produk yang telah dikembangkan yaitu berupa suplemen penuntun praktikum Taksonomi Tumbuhan II telah layak dengan persentase akhir yaitu 76,39\% dan dapat dilakukan uji keterbacaan. Suplemen yang telah direvisi berdasarka saran dari validator selnjutnya dilakukan uji keterbacaan terhadap mahasiswa yang menempuh matakuliah Taksonomi Tumbuhan II yaitu mahasiswa pendidikan biologi Universitas Bengkulu. Hasil uji keterbacaan yang telah dilakukan kepada 35 orang mahasiswa, didapatkan hasil uji keterbacaan secara keseluruhan yaitu sangat layak atau sangat valid. Dari semua hasil analisis data dari uji 
keterbacaan yang telah dilakukan maka didapatkan rata-rata kriteria/hasil uji yaitu sangat valid dengan rata-rata persentase 86\%. Kevalidan diperoleh dari kriteria persentase penilaian dari validator berdasarkan penilaian setiap aspek suplemen penuntun praktikum.

Berdasarkan hasil analisis pada tabel data uji keterbacaan menunjukkan bahwa suplemen penuntun praktikum mendapatkan hasil dengan kriteria sangat layak digunakan sebagai media pembelajaran yang membantu proses pembelajaran Taksonomi Tumbuhan II, hal ini dilihat dari respon mahasiswa dalam menilai aspek-aspek yang terdapat dalam penuntun praktikum. Maka suplemen penuntun praktikum yang dikembangkan dapat digunakan sebagai bahan ajar matakuliah Taksonomi Tumbuhan II terutama pada materi etnobotani. Hasil tersebut didukung oleh Akbar (2013) yang menyatakan bahwa media pembelajaran dapat dikatakan layak bila rata-rata persentase dari angket validasi ahli media, ahli materi dan respon siswa diatas $70 \%$.

Selain itu pengembangan bahan ajar dalam bentuk suplemen penuntun praktikum berdasarkan studi etnobotani dan pemanfaatan mengenai mangrove ini dapat mendorong peserta aktif dalam proses pembelajaran. Karena bahan ajar ini menuntut peserta didik untuk bekerja sendiri. Hal ini sesuai dengan Suwarjo (2013) dan Syah (2011) penggunaan bahan ajar dalam bentuk penuntun praktikum dapat menunjang keaktifan peserta didik dalam kegiatan pembelajaran secara lebih optimal.

Salah satu kelebihan dari bahan ajar suplemen penuntun praktikum ini dikembangkan berdasarkan studi etnobotani pemanfaatan mengenai mangrove bagi masyarakat di kawasan Kota Bengkulu. Adanya pemanfaatan studi etnobotani mangrove sebagai sebagai sumber belajar ini dapat memudahkan mahasiswa pendidikan biologi Universitas Bengkulu dalam proses belajar karena objek atau materi yang dipelajari sangat dekat dengan mereka.

Hal ini sesuai dengan penelitian Handini (2018) yang menyimpulkan bahwa bahan ajar yang berorientasi pada karakteristik dan kearifan lokal suatu daerah lebih memberikan kesan yang nyata dalam pembelajaran sehingga peserta didik mudah memahami materi yang dipelajari. Tivani (2016) yang menyatakan bahwa permasalahan yang diangkat dalam pembelajaran harus berasal dari permasalahan nyata yang dihadapi peserta didik. Pitasari (2018) juga menjelaskan bahwa ilmu biologi merupakan ilmu yang berkaitan erat dengan peristiwa yang terjadu dalam kehiupan sehari-hari .

Kritik dan saran didapatkan dari beberapa mahasiswa yang telah mengisi angket uji keterbacaan mahasiswa antara lain yaitu mengenai pengurangan kesalahan penulisan pada suplemen penuntun praktikum telah dikembangkan oleh penulis dan sudah diperbaiki, hanya saja dibeberapa kata memang masih ada kesalahan yang harus diperbaiki. Menurut Susanto (2013) menjelaskan bahwa tampilan sebuah buku itu harus menarik, mampu menggerakkan orang untuk membacanya, mudah untuk dibaca dalam hal ini jenis dan ukuran hurufnya tidak terlalu kecil dan enak dibaca, urutan teks terstruktur dan tersusun rapi. 


\section{PENUTUP}

Simpulan

Adapun kesimpulan dalam penelitian ini bahwa setelah dilakukan perancangan suplemen penuntun praktikum kemudian dilakukan uji validasi terhadap ahli materi dan ahli bahan ajar. Hasil uji validasi adalah 76,39\% dengan katagori "valid". Masukan dan saran dari validator menjadi acuan untuk dilakukan revisi. Kemudian dilakukan uji keterbacaan terhadap mahasiswa pendidikan biologi yang menempuh mata kuliah Taksonomi Tumbuhan II dengan persentase $86 \%$ dengan kategori "sangat layak".

\section{Saran}

1) Diharapkan untuk peneliti selanjutnya dapat mengembangan penelitian ini dengan skala yang lebih luas.

2) Bagi mahasiswa dan dosen dapat menjadikan suplemen penuntun ini sebagai penuntun pada materi etnobotani di kampus.

3) Bagi program studi pendidikan biologi bisa dijadikan arsip atau digunakan untuk mencapai suatu tujuan pembelajaran.

\section{DAFTAR PUSTAKA}

Akbar., Sa'dun. 2013. Instrumen Perangkat Pembelajaran. Bandung: Rosdakarya.

Handini,M.N. 2018. Studi Etnobotani Tumbuhan Obat Suku Serawai Sebagai Pengembangan Handout Biologi Kelas $X$ SMA. Diklabio: Jurnal Pendidikan dan Pembelajarn Biologi 2 (2) : 35-43. (Online). (https://ejournal.unib.ac.id/ index.php/ippb/article/view/6802).

Diakses 8 Januari 2019.

Noor, Y.R., M. Khazali, dan I.N.N Suryadiputra. 2006. Panduan Pengenalan Mangrove di Indonesia. https://indonesia.wetlands.org/id/pu blikasi/panduan-pengenalanmangrove-di-indonesia . (Diakses 8 januari 2019).

Martin G.J. 1998. Etnobotani. Natural History Publication dan WWF. Malaysia.

Pitasari, Y., Abdul, R., Kasrina. 2018. Pengembangan Lembar Kerja Peserta Didik Berdasarkan Studi Pengaruh Osmosis Terhadap Warna Mata. Diklabio: Jurnal Pendidikan dan Pembelajarn Biologi 2 (2) : 16-21. (Online). (https://ejournal.unib.ac.id /index.php/ippb/article/view/6799). Diakses 08 Januari 2019.

Purwanto, Y., 2000. Etnobotani dan konservasi plasma nutfah hortikultura : peran sistem pengetahuan lokal pada pengembangan dan pengelolaannya. Prosiding Seminar Hari Cintapuspa dan Satwa Nasional. Vol (4)3 : 56-62. http://repository.ipb.ac.id/bitstream/ handle/123456789/52308/Daftar Pus taka.pdf. 8 Januari 2019.

Riduwan. 2015. Skala Pengukuran Variabelvariabel Penelitian. Bandung: Alfabeta.

Rustaman. 2005. Buku Strategi Belajar Mengajar Biologi. https://www. researchgate.net/publication/328718 176 Buku Strategi Belajar Mengajar Biologi . (Online) (diakses 20 Januari 2019).

Sugiyono. 2012. Metode Penelitian. Bandung: Alfabeta.

Susanto, Ahmad. 2013. Teori Belajar dan Pembelajaran di Sekolah Dasar. 
Jakarta: Kencana Prenadamedia Group.

Suwarjo.2013. Pemanfaatan Media Pembelajaran Berbasis Lingkungan. Yogyakarta: UNY.

Syah, Muhibbin. 2011. Psikologi Belajar. Jakarta: Rajawali Pers.

Tim Penyusun Program Studi Pendidikan Biologi. 2017. Rencana Pembelajaran Semester (RPS) Program Studi S1 Pendidikan Biologi JPMIPA FKIP UNIB.

Tim Penyusun Program Studi Pendidikan Biologi. 2018. Kurikulum Pendidikan Biologi FKIP UNIB.

Tivani, I., Paidi. 2016. Pengembangan LKS Biologi Berbasis Masalah untuk Meningkatkan Kemampuan Pemecahan Masalah dan Karakter Peduli Lingkungan. Jurnal Inovasi Pendidikan 2(1): 35-45. (Online). (https://journal.uny.ac.id/index.php/i ipi/article/view /8804). Diakses 8 Januari 2019.

Widarmayanti, R. P., Susantini, E., dan Ambarwati, R. 2015. Profil Validitas LKS Berbasis Keterampilan Proses Pada Subpokok Bahasan Invertebrata Untuk Kelas X SMA. Jurnal Bioedu. Vol (4) 1. Surabaya: Jurusan Pendidikan Biologi FMIPA Universitas Negeri Surabaya. 